University of Nebraska - Lincoln

DigitalCommons@University of Nebraska - Lincoln

French Language and Literature Papers

Modern Languages and Literatures, Department

May 2001

\title{
Separation, Mourning, and Consolation in La Route d'Altamont
}

Thomas M. Carr Jr.

University of Nebraska - Lincoln, tcarr1@unl.edu

Follow this and additional works at: https://digitalcommons.unl.edu/modlangfrench

Part of the Modern Languages Commons

Carr, Thomas M. Jr., "Separation, Mourning, and Consolation in La Route d'Altamont" (2001). French Language and Literature Papers. 19.

https://digitalcommons.unl.edu/modlangfrench/19

This Article is brought to you for free and open access by the Modern Languages and Literatures, Department of at DigitalCommons@University of Nebraska - Lincoln. It has been accepted for inclusion in French Language and Literature Papers by an authorized administrator of DigitalCommons@University of Nebraska - Lincoln. 


\section{By Thomas M. Carr, Jr. \\ University of Nebraska-Lincoln}

Gabrielle Roy's first novel was permeated by loss and separation; its title Bonheur d'occasion (1945) even suggests the attempt at replacement that, as we shall see, often is part of consolation. However, the central role of mourning in Roy's works has only come into sharp focus with the appearance of her posthumous texts. The first part of her autobiography published in 1984 included an account of the death of her father; the culmination of the Lettres à Bernadette (1988) is her anticipated mourning for her dying sister, ${ }^{1}$ and the initial stages of her grief work for her mother occupy the whole of the Le Temps qui m'a manqué (1997). In fact, the 1943 death of her mother Mélina Roy, which she relived first in the death of her sister Anna in 1964, and even more intensely through the death of her dear Dédette six year later in 1970, penetrates most aspects of her writings. In a sense, much of her corpus is structured around the sorrow provoked by separation, whether the death of a loved one, an absence caused by a departure, or a more general feeling that life itself is inevitably marked by the pain of being profoundly cut off from what one loves. The countervailing force to this distress is the quest for relief, for consolation. As she put it around 1978, "me laisser consoler de je ne sais quelle détresse qui me venait et me vient encore après m'être laissée aller à beaucoup espérer des hommes."2

Modern psychology since Freud has theorized the search for a remedy for losses as grief work, a term that Roy herself does not seem to have commonly employed. On the other hand, she does use a related one, consolation. The strategies of consolation developed by the ancient moralists and adapted by the Church overlap to a large extent with the social and psychological domains that are studied today in terms of grief work, and the word "consolation" would have been common currency when speaking of this comfort in the Catholic milieu of Roy's youth. While she never systematically formulates her attitude toward loss in terms of consolation, and although her approach does not rely on the power of the reason and the will to overcome sorrow as is the case in many of the more traditional consolatory methods, the fact that the word appears more and more frequently in her autobiographical texts and letters when she talks about the death of her parents and sisters is indicative of its importance to her. In June 1960 she writes to Bernadette: "Combien tes lettres me font du bien toujours! Est-ce parce que tu sais voir le côté consolant de la vie" (48)? Twenty years later she will reiterate this idea in an effort to console her dying sister: "Je ne me rappelle pas une lettre de toi, par exemple, qui ne m'ait consolée. . ." (222). ${ }^{3}$ If thirteen forms of the word are found in all of Bonheur d'occasion, ten are found in the first four chapters alone of La Détresse et l'enchantement. Moreover, Roy seems to have seems to have envisaged her books as bringing consolation to her public. In her 1979 interview with Gilles Dorion she speaks of her satisfaction at learning that a lonely young Vietnamese woman in Montreal had been consoled by reading La Rivière sans repos (1970) published nine years earlier (35).

My approach combines the insights of the modern reflection on loss stem-

Copyright (C) 2001 the American Council for Québec Studies. Used

by permission.

solatory tradition. This eclecticism is justified because neither current is 
homogeneous. The Freudian vulgate has been increasingly contested by theorists and ignored by practitioners of grief therapy who ground their treatment in more behaviorist or cognitive models. Perhaps the most pertinent reformulation of Freud's 1917 essay "Mourning and Melancholia" for my purposes is the attachment theory of John Bowlby who expands the notion of loss in Freud to include various forms of separation: for example, Bowlby's stress on the attachment of infants to their mothers as a model for future attachments and his discussion of separation anxiety as a prelude to adult mourning. ${ }^{4}$ If there is one point on which all modern theorists agree it is that the mourning process unfolds in a series of stages. Although every theorist describes the phases somewhat differently, the consensus holds that after an initial period of shock that can include physical symptoms and denial, mourners enter a longer depressive period that can include rumination and searching for the lost object before finally detaching themselves from it and reorganizing their world without it (Hanus 92-115)

Consolation can be seen as occupying the middle and concluding stages of what is now called grief work, or it can be seen as a distinct approach to mourning. However, while Freudian grief work stresses the libido's detachment from the lost object, the much older tradition of consolation focuses more on accepting some replacement for the loss. Consolation is not needed when full compensation for the loss is available. ${ }^{5}$ Thus, in the Christian tradition, heaven replaces consolations that might be needed on earth for losses experienced there. ${ }^{6}$ But when the substitute is perceived as being of inferior value or as not completely replacing the loss, consolation comes into play. As David Payne puts it:

Consolation occurs when some sort of comfort is accepted, usually in the form of a substitute for what has been lost... To console is to persuade to a different order of valuations wherein a new perspective on the loss is possible. In consolation, loss is neither denied nor erased. Consolation minimizes and diverts attention from loss and painful consequences. (42)

The adjustment process needed to accept this replacement is simultaneously intellectual and affective, although the proportions of each will vary from case to case. The stoic consolatory current privileges the mind: first the understanding strives to place the loss in a more favorable perspective or to embrace a different order of values that would make a substitute acceptable; then the will imposes acceptance of this vision on the often reluctant emotions. A second tendency within the consolatory tradition sees grief less as an opponent to be mastered by the intellect and the will than to be seduced by the emotions: it seeks to calm the pain caused by the loss and eventually to substitute more satisfying affects for the hurt.

Acceptance of a replacement in consolation does not mean that the loss is completely erased or denied; the substitute is perceived as not being a complete replacement, and thus the memory of the lost object persists with the substitute. Moreover, consolation is not easily achieved, and the quest for a substitute often proposes consolations, whether intellectual or affective, that are discovered eventually to be illusory. Thus, when assessing a potential replacement, there is always the danger that a positive evaluation will be bestowed more on the basis of wishful thinking than on a realistic appraisal; intense emotional experiences may prove to be transient and bring no stable relief

\section{Two Stories}

Before examining La Route d'Altamont in detail, it will be useful to compare two stories from other collections, both turning on funerals and set in Manitoba that exemplify two poles found throughout Roy's entire corpus: an emotional experience that transcends the pain of loss and a dejection that makes any consolation seem futile.

The pain of separation is overcome by means of an overwhelming enchantment in "De quoi t'ennuies-tu, Eveline?" The price of Eveline's freedom in her widowhood, established in the story's first framing chapter, is "la douleur des séparations" (11). However, the rest of the novella recounts "sa récompense" (11) which abolishes all separation. Solicitously doted on by strangers during her lengthy bus trip from Winnipeg to California, even though she arrives to find her bother Majorique already dead, she has not really lost him. In fact, she finally discovers his real talent as a rassembleur in the multinational family he had gathered around himself on the hills overlooking the Pacific. His funeral is a joyous procession of life that culminates in Eveline's discovery of the sea as a symbol of the mystery of the infinite. Thus the reality of separation affirmed in the opening section of "De quoi t'ennuies-tu, Eveline?" gives way to a vision of union with other humans and the natural world that is more powerful than the sadness that characterizes life.

On the other hand, the framing question of "L'Enfant morte," 8 the only story set in Manitoba in Cet été qui chantait (1972), suggests that the joy experienced by the contact with nature is not powerful enough to permanently overcome the "tristesse" of the human condition: "Pourquoi donc le souvenir de l'enfant morte, tout à coup est-il venu me rejoindre en plein milieu de l'été qui chante" (143)? The elderly narrator's communion with nature during her summers in Charlevoix is interrupted by disturbing memories. As a beginning school teacher, she had mourned the attachment she never had the chance to establish with a pupil she found dead when she arrived at her new post. She leads the dead Yolande's classmates in traditional funeral rites: giving testimonials to the deceased's worth, watching over the body, and gathering gifts of flowers until they attain some measure of consolation: "Je les écoutais se consoler déjà, comme ils pouvaient, de la vie..." (149). The "comme il pouvaient" signals the tentative character of the children's consolation: Yolande's own premature death is a symbol of a more generalized failure afflicting all humanity: "les efforts humains en fin de compte sont voués à une sorte d'échec" (145)

The intense emotional communion with nature and loved ones in "De quoi t'ennuies-tu, Eveline?" can be seen more as superior mode of being than as a replacement of lesser value for Eveline's losses; this would make it, in effect, more an erasure of loss and separation that obviates the need for grief work than a true consolation. On the other hand, "L'Enfant morte" recalls the assessment of Miodrag Kapetanovich, who pronounces a negative verdict on the Manitoban writer: "L'œuvre ne console pas. Elle aggrave le mal de vivre" (Morisset 241). The tension between an enchantment that transports beyond mere consolation and a dejection immune to relief was always present in Roy's fiction. That it reflects a fundamental preoccupation in her personal life becomes clear when we examine the explicitly autobiographical texts she began to produce in the late 1970s. The polarity, for example, can be seen in "Ma petite rue qui m'a menée autour du monde" written around 1978 (PBO 41-62) and culminates, of course, in La Détresse et l'enchantement that she began around 1977 and worked on until her death in 1983. 
Rather than study how she finds a consolation that mediates between these two extremes in her autobiographical writing from the end of her life, I will examine it in fiction from her middle period in the 1960s. What has been called the Manitoban cycle of Roy, where she transposes the experiences of her youth often while romanticizing them, lends itself particularly well to a study of this tension. Of the fiction set in Manitoba, it is in La Route d'Altamont (1966) that separation is treated in the most extensive way, so much so that Christine Robinson has called it a "récit de deuil" (145). Moreover, there is a movement toward consolation in this novel, with explicit references to it in three of its four stories.

In 1966, readers might not have been aware of the autobiographical nature of the novel, but readers with access to La Détresse can hardly ignore this point. Of all the Manitoban fiction, La Route d'Altamont covers the longest span of time: from its protagonist Christine's early childhood to her young adult years. It thus corresponds to events from Roy's own life recounted in the first part of $L a$ Détresse and culminates, like the first part of the autobiography, with its heroine's departure for Europe ${ }^{10}$ Two of the four stories that comprise the collection were begun in the late fifties, and then reworked in the early sixties when the other two were composed (Ricard 398). All were finished when the collection put together after Anna's death in 1964. If this fiction finds its inspiration in Roy's own life, writing it also became for her a source of personal consolation. Roy herself noted that fictionalizing her departure in La Route d'Altamont allowed her to transcend the pain of the experience (DE 183), so that as critics have pointed out, her Manitoban fiction becomes a remedy for losses suffered in Roy's life. Carol Harvey calls Ces Enfants de ma vie (1977) "une fiction compensatoire," "une cuvre de consolation" (47-48).

It is thus necessary to keep in mind three somewhat overlapping levels. Within the fiction, Christine and the other characters seek consolation for the losses and separations they experience. Second, by recasting the separations of her youth into fiction, Roy herself seeks consolation for the stresses her family life caused and continued to cause her, even as she wrote; her letters and essays can give further insight into this personal search for consolation that in turn is reflected in the kinds of consolation she proposed for her characters in her fiction. Finally, readers of the novel may not come to it seeking consolation, but if they enter into its spirit, they will be forced to grapple with issues of loss and the quest for relief.

La Route d'Altamont thus offers a unique site for examining the intersection of grief work and consolation. The novel opens, of course, with the death of Christine's grandmother and closes with that of her mother, and includes passages where all three women consider their own mortality. Nonetheless, the real subject of the collection is perhaps less the pain caused by the separation of death, than the anguish caused by Christine's departure for Europe. The following section of the article will examine each story of the novel in turn from the perspective of the characters in order to analyze the forms of consolation proposed for these three separations: the pain caused by leaving loved ones, by the death of those who are dear, and by the thought of one's own eventual passing. The concluding section assesses the efficacy of these consolations in terms of Roy's personal struggle with grief and separation.

\section{"Ma grand-mère toute-puissante" and "Le Vieillard"}

All three forms of separation come into play in the novel's opening story, "Ma grand-mère toute-puissante." The young Christine herself, who has been exiled from the city to spend the summer in her grandmother's village, is presented initially as the character in need of consolation. But she does not experience this move as a painful exile in the way her grandmother had suffered when forced to leave home and family in Quebec for the Manitoba plains; Christine only suffers from boredom, not a feeling of being torn from persons and places to which she is deeply attached. This is perhaps why the doll that her grandmother makes, explicitly to console her (13), is a pastime that diverts her from her ennui, rather than a more sophisticated form of emotional or intellectual consolation. Indeed, her grandmother might be said to find the most consolation in the process, for making the doll allows her to feel useful once again, and thus to compensate in some way for her growing sense of being cast to the sidelines by old age. As the old woman further declines, Christine in turn consoles her grandmother by showing her the photo album containing pictures of her descendants. Christine seems to sense instinctively that by making mémère feel "entourée," surrounded by family, she somehow helps console her for the loss of faculties and impending death. The continuing existence of the extended family becomes a substitute for mémère's rapidly fading life. For the same reason it brings consolation to Christine's mother whose "petit sourire triste" (35) signals both a respite in her sadness over losing her own mother and contentment that her daughter continues the family tradition.

The older narrator tells us that as a young girl, she did not yet know the meaning of death. She had only experienced it as "une absence," as "une disparition" (35), rather than as a definitive separation. However, her grandmother's death changed this since the next story, "Le Vieillard et l'enfant," is announced as a tale of consolation brought to bear on grief work: "Longtemps je fus malheureuse de la mort de grand-mère. Puis vint un été étrange. Comme pour être consolée, je fis la connaissance d'un doux et merveilleux vieillard" (39). Monsieur Saint-Hilaire does not replace mémère, but puts Christine in touch with emotional experiences and understanding that brings her some relief.

Christine has a reoccurring vision of her dead grandmother that brings her to feel fully the impact of her loss. Christine recounts her visits to the little grove of trees near her home where she recalled "le visage dur comme pierre" (42) of her grandmother in the open coffin. At that point she maintains that she did not yet understand that death awaited every human, "nous tous" (42). Later with Monsieur Saint-Hilaire she visualizes her grandmother, not as dead but busily sewing, and experiences her grandmother's death as an abandonment. Her death is not just an absence but a diminishment. When she finally realizes the universality and finality of death, "la vérité de la vieillesse et à quoi elle mène" (82), she is struck by a generalized sadness, "un chagrin," that leaves even the beauties of nature "ternes et comme délaissées" (81).

The overwhelming joy that she experiences when she finally reaches the lake's edge is only the beginning of the consolation promised in the story's first paragraph. The consolation becomes deeper and more lasting because it only arrives slowly as she reflects on her experience, guided by her discussion with Monsieur Saint-Hilaire. 
Gradually the old man brings her to view her grandmother's death, indeed all death, within two patterns that minimize the separation that death implies. The first is to situate death within nature symbolized by the lake. The lake represents a permanence that restores all loss. The lake is both old and young at the same time, constantly changing and yet immutable: "La fin, le commencement?... Et si c'était la même chose au fond?" (74). For those who die old at the end of complete life cycle, death is not unjust, but natural (82). Situating the death of individuals within this larger pattern neutralizes the fear it provokes; death becomes simply part of a larger pattern of continuity.11 SaintHilaire's second line of argument is less impersonal, more likely to comfort someone mourning the loss of a loved one. He evokes a mysterious country "de l'autre côté" where one is reunited with everyone and everything one loves (83). On the most literal level, this "pays magique" seems to deny the separation of death with the promise of an afterlife; at the same time by insisting that it is "un pays de l'amour" (86), he suggests that there is a communion among loved ones that merely continues after death. Just as when one person is missed profoundly the world seems deserted ("une seule personne venant à nous manquer, la terre peut nous paraître un désert" [78]), when a single person is bestowed on us, we feel as if we possess the entire world ("un seul être nous étant donné, c'était dès lors comme si on possédait le monde" [86]).12 Love is at once the cause of grief and its remedy. Christine longs to crisscross this "beau pays" but at the same time the old man, while assuring her that she will one day know it, expresses fear on her behalf (87) perhaps because of the pain that will likely accompany a loving attachment to another. This might explain the mixed quality of the voice of the lake, reassuring and melancholy ("plaintive et douce" [87]) at the same time, or the call of the loon, sad and yet enticing (80).

\section{"Le Déménagement" and "La Route d'Altamont"}

In "Le Déménagement" the theme of Christine's departure, which had been subordinate to grieving deaths in the first two stories, takes prominence. In "Le Vieillard" she had left with her mother's permission to visit the lake her mother had never seen; here she leaves for the day without permission. In "Le Vieillard" she had realized that wanting to leave is not enough (89); ties of attachment can prevent one from leaving, as they had in her mother's case. In this third story she justifies her disobedience by noting that desire itself can fade and that one must at times act before it does (99). Nonetheless, at the end of the story, Christine eventually must seek consolation for the death of a cherished dream, consolation for a desire that is revealed to be an illusion.

The young Christine saw moving as adventuresome separation, as an almost heroic act of pulling up roots that breaks the monotony of everyday life (96). But projecting on to Winnipeg's unfortunates this sense of adventure nurtured from her mother's stories of the family move from Quebec quickly proves disastrous. She tries to console herself with the idea that the move these poor people are making will snatch them away from their miserable lives and lead them to better quarters: " $j$ 'eus pour me consoler cette idée: on est venu arracher ces gens à cette misérable vie" (106). However, this consolation quickly is revealed to be illusory when the wagon arrives at lodgings more squalid than the last. Roy had first mined this theme in Rose-Anna's annual frantic search for a new apartment in Bonheur d'occasion. She recounts in a 1974 text published in Le Pays de Bonheur d'occasion how she impersonated such a desperate renter as part of her research for the novel, summing up the illusory consolation with brutal pessimism: "[L]a grande masse semblait partir de son plein gré comme pour se donner l'illusion de la liberté. Ils en était malades, eussent été n'importe où quand se réveillait en eux, le printemps, la lancinante douleur de l'arrachement originel qui donnait naissance au terrible espoir que ça ne pouvait être pire ailleurs" (98).

Back at home, Christine's mother's embrace soothes the "détresse de désillusion" (112) of her daughter's wishful thinking. However, this gesture of solidarity does not bring permanent relief. Just as the thought of growing old and dying had taken all the color out of the world for Christine in "Le Vieillard," the move reveals to Christine "ce côté usé, terne et impitoyable de la vie" (112). This realization steels her own determination to leave home; it is more powerful than the immediate consolation of her mother's hugs and the security of familiar family life.

The intertwined nature of the themes of death and leaving home becomes clear in the collection's last story. On the one hand, the fact that moving is not just a risky adventure, but a painful breaking of ties becomes evident, and on the other we see that death, the supreme separation, is sometimes hastened by sorrow for lost attachments.

In "La Route d'Altamont" consolation seems initially required chiefly by the mother who has not stopped grieving the loss of the Quebec of her childhood. The lost foothills of the Laurentians symbolize her attachment to a youth that is fleeing her and of the need to confront her own mortality. One can identify a number of forms of consolation, all of which mitigate the extent of the separations she had already experienced or that she fears for the future. First, Eveline's intense joy in discovering the mysterious road that leads to the heart of the Pembina hills reminds her of her childhood in Quebec and is comparable to the happiness experienced by Christine upon seeing Lake Winnipeg. It will only be later that the older Christine as narrator will understand the meaning of this joy: that the hills restored to her mother "sa joyeuse âme d'enfant" (127), providing a point of continuity between her youth and old age. But the mother had a second consolation for her lost youth, the consolation of parents who live on in their children (146). Just as Eveline eventually recognized resemblances between herself and her own mother (138), she lives again in Christine (146). In a sense Eveline only makes explicit the power of the solidarity of generations to overcome death first alluded to in the photo album Christine had showed her grandmother. This immortality through one's children is independent of life after death, unlike the communion with loved ones "de l'autre côté" described by Monsieur Saint-Hilaire.

Just how fragile these consolations are for Eveline becomes evident when they are jeopardized by her daughter's departure. When Eveline and Christine make a last trip toward Altamont, they are no longer sure they have found the hills; has the enchantment vanished or can they no longer find the secret road into the Pembina escarpment? Once the couple has been dissolved by the projected desertion of one of its members, the solidarity symbolized by the common possession of "nos collines" (151) is lost for both.

In fact, Eveline is forced to concede that some measure of separation is necessary to her daughter's project of becoming a writer. The mother simply maintains that Christine need not make the radical break of leaving family and Winnipeg. "Ici comme ailleurs," she states, "il y a à décrire la joie, les chagrins, 
les séparations" (147). Moreover, if the goal of departure is to go beyond one's current self toward something new, need one really travel? Eveline suggests that love and marriage, because of the almost inevitable tensions between partners, might be said to constitute "le seul chemin pour avancer un peu hors de soi" (140).

Christine, however, does her best to minimize envisaging her departure in terms of separation. She claims that she has increasingly felt herself a stranger in Saint-Boniface (145) and has come to believe, based in part on her mother's stories, that France is her true "vieille mère-patrie" (147). Moreover, instead of betraying her mother by leaving, Christine claims that she is only following the spirit of one who had so ardently desired to leave herself (147). Lastly, she proposes new trips with her mother when she returns from Europe and finally has money (155). The wishful thinking that culminates in this last argument is only too apparent to her mother who realizes that her daughter is bent on a separation. Christine reports that her mother "me lança un regard si aigu, si désolé, si seul, que je n'osai poursuivre" (155).

Christine prefers to see the positive side of separation. Instead of stressing the pain that separation entails, she presents it as an opportunity for discovery. Just as only by leaving Quebec had her mother discovered Manitoba, Christine suggests that only by abandoning things that are dear that can one make discoveries. When her mother retorts, "Oserais-tu me dire que pour découvrir il faut tout abandonner?" Christine asserts, "Certaines choses en tout cas" (148)

Only in the 1977 Ces Enfants de ma vie will this vision of life as a series of painful separations that are the price of growth be made fully explicit in the Manitoba fiction. In "La Truite dans l'eau glacée" the narrator notes that she had learned that "si la vie donne d'une main, elle reprend de l'autre" and that "pour avancer d'un pas dans la voie de l'accomplissement ou de la simple réussite, on s'arrache chaque fois à quelque bien peut-être encore plus précieux" (205). The narrator of Ces Enfants hopes to escape this cycle of separation by establishing some lasting attachment: "Ma vie allait-elle être cet arrachement continuel pour conduire, à la fin, à quel attachement donc qui durerait" (207)? However, Christine in La Route d'Altamont seems less interested in finding some enduring human attachment than the narrator of Ces Enfants. In La Route d'Altamont there is no hint of romantic links. Has the pain of tearing herself from her mother caused Christine to shy away from love or marriage? Unlike the narrator of Ces Enfants, the expectations of Christine in La Route d'Altamont center on her projected career as a writer.

Having successfully grieved her grandmother's death with the help of Monsieur Saint-Hilaire, Christine no doubt feels she will have the strength to overcome the pain of leaving her mother and Winnipeg. However, it is one thing to find consolation for a death in which one had no responsibility, such as the death of Christine's grandmother; it is quite another to come to grips with a separation that one has willed. Christine does take responsibility for her mother's death insofar as the older narrator Christine admits with hindsight that Eveline's death was perhaps caused by "chagrin" as well as by illness (156). Nonetheless, this mature narrator attempts to minimize her guilt: she attributes the mania to leave of her younger self to a stranger within herself, a stranger who is indifferent to the suffering she will cause (143). She notes too that her mother at least pretended to approve of her daughter's trip to Europe. Although this approval could have come in one of Eveline's letters "menteuses," it might also indicate that Eveline did begin to find consolation in the discoveries her daughter was making.

Finally, the older narrator Christine suggests that her mother found the supreme consolation in the mysterious country first described by Monsieur Saint-Hilaire. There her mother overcame the sadness of her last years: "Son âme capricieuse et jeune s'en alla en une région où il n'y a sans doute plus ni carrefours ni difficiles points de départs. Ou peut-être y a-t-il encore par là des routes, mais toutes vont par Altamont" (156)

We are now positioned to see how the consolations proposed to readers in La Route d'Altamont are situated between the two Manitoba stories I began with. While "L'Enfant morte" is dominated by a generalized sense of the futility of all human efforts, each of the stories of La Route d'Altamont ends on a more positive note than the "pesante tristesse" (145) that was barely relieved by the rites of mourning the school teacher organized for her dead pupil. On the other hand, the evocation of an enchanted region that ends La Route d'Altamont has closer parallels with the two powerful antidotes to separation-solidarity and the rapture of nature-experienced so intensely by the mother in her vision of the sea at the end of "De quoi t'ennuies-tu, Eveline?" Nonetheless, there are major differences. In "De quoi t'ennuies-tu, Eveline" the mother achieves her communion so effortlessly that it skirts the even more extreme example of the "terrible bonheur" (56) that the singing of the young Nils in "L'Alouette" of Ces Enfants de ma vie unleashed, a magic that owed much to its power to evoke "la vie du rêve" (59). ${ }^{13}$ Eveline's mourning for the death of her brother is accomplished magically, and the need for consolation is obviated. In La Route d'Altamont the mother does not regain in this life the enchantment she had once experienced in the Altamont hills. The narrator merely states that her soul reached this mysterious region. Postponing permanent joy until after death is a reminder that consolation in this world is always temporary and provisional.

Although Altamont resonates with the mysterious country of love "on the other side" evoked by Monsieur Saint-Hilaire, the narrator Christine does not promise reunion with her mother there or suggest that her mother will live on in her daughter's writing. Moreover, the promise of a sort of permanent enchantment for her mother is really as much a consolation for Christine, who attempts to assuage her guilt by assuring herself that her mother achieved after death the consolation that Christine denied her in life. There is an element of wishful thinking, both for Christine and for her mother, in this Altamont attained after death.

\section{The Author and Her Creation}

Roy herself was not immune to this process in which desire becomes a motor of consolation, as she herself admits in narrating her efforts to comfort her dying sisters. Her own belief in an afterlife and her elaboration of an idiosyncratic form of faith that put more stock in communion with loved ones than with God (Ricard 413-14) was born of her dying sister Anna's desperate need to believe in a God who awaits us after death. Roy recounts in La Détresse how her desire to reassure Anna led her to affirm the existence of a being who loves and waits for us, "Je m'étais prise à ma propre piège... à travers une inconsolable détresse... j'ai recommencé à vouloir Dieu à tout prix" (165). It is certainly not coincidental that La Route d'Altamont, where the idea of a country on the other side plays such an important role, was put together in the wake of Anna's death 
in 1964. This pattern of shaping her consolatory arguments to the desire of those she sought to console remained a constant of Roy's own practice. She tells in her letters and autobiography about trying to persuade the dying Bernadette that the nun had lived life more intensely than many in the world (LB 210-211). She offers the dying nun hope that these all too short moments of joy can be a bridge to the permanency of immortality:

Les moments de joie sont des moments arrachés au mystère de l'éternité. Pour ma part, j'ai toujours cru que c'est aux moments d'exaltation que nous sommes le plus près de la vérité suprême de la création. Fie-toi à la joie qui est venue tant de fois habiter ton âme. C'est elle, ma Dédette, qui dit vrai, qui ne nous trompe jamais, elle qui nous mène au Seigneur... La joie radieuse toute pareille à l'émouvante beauté d'une journée d'été au bord du grand lac Winnipeg! (224)

While La Route d'Altamont has its moments of bleakness and wishful thinking, on the whole Roy allows neither to dominate the novel. She finds a middle ground in it between "une inconsolable tristesse" (DE 165) and overly facile compensations that reveal themselves to be illusions. Unlike "De quoi t'ennuies-tu, Eveline?," La Route d'Altamont does not conceal the difficulty of achieving, much less sustaining, mutual tendresse in the face of obstacles like age differences or ambition. ${ }^{14}$ Likewise, these stories do not attempt to hide the transience of intense joy. As Roy noted in her 1979 interview with Gilles Dorion: "De par sa nature la joie ne peut durer" (33). And indeed, at the end of Christine's afternoon at Lake Winnipeg the sounds of the lake turn monotonous and lull Christine and Monsieur Saint-Hilaire to sleep (88), just as she "loses" the road in the hills in the last story.

In the interview with Dorion, Roy identified "la tendresse humaine" as the "remède à la douleur de vivre" (33). In La Route d'Altamont this tenderness takes the form of a solidarity that unites humans and that is evoked the most explicitly by Monsieur Saint-Hilaire's description of the "pays de l'amour" (86). The novel suggests that one potent consolation is found in moments of shared tendresse-the making of the doll, leafing through the photo album, or the joy of "nos collines." In her account of the deaths of both Anna and Bernadette, Roy herself fervently insisted on this love, which Lori Saint-Martin characterizes as a feminine "éthique de la sollicitude" (132). Love pushes us to console one another; and as Roy learned from her months spent trying to console the dying Bernadette, she herself found consolation in the attempt. ${ }^{15}$

Moreover, in La Route d'Altamont Roy counts on reflection and understanding to mitigate wishful thinking and to add some measure of intellectual substance to the exhilaration of nature. Certainly, Christine's emotional experience of the lake is crucial to the consolation she finds there, and the memory of sounds like the loon's call that haunt her many years later confirms the power of nature to console. Still, in "Le Vieillard et l'enfant" nature's voice is mediated by reflection that is not found in "De quoi t'ennuies-tu Eveline?" From Monsieur Saint-Hilaire's description of the circularity of nature symbolized by the distant shores of the lake (75) to his observation that death in old age is not against the order of nature (82), his success in drawing out meaning from the experience of the natural world makes the consolation of nature more potent and long lasting. Likewise Eveline's discovery of the road through the hills is accompanied by a discussion with her daughter of how parents live on through their children (138 41,145-49). The most enduring consolations seem to combine the experience of the natural world in the company of loved ones with interpretation that makes it intelligible. Emotion must be seconded by understanding.

This consolation allows La Route d'Altamont to be less bleak than the reading Roy herself gave of the novel about ten years after its publication, as reported in La Détresse, where she stresses the "déchirante vérité" of separation as its theme. Around 1976 when Roy was sixty-seven, the age of her mother when Roy left Saint-Boniface, she came to believe that children cannot understand their parents' solitude until they have reached the same age:

Maman, à cette époque, allait sur ses soixante-sept ou soixante-huit ans. L'âge que j'ai maintenant, alors que je prends le temps enfin de m'interroger sur ce qu'elle a pu ressentir d'infini chagrin. Tout cela est bien curieux. Il semblerait que l'on ne rejoint vraiment ses gens que lorsqu'on atteint l'âge qu'ils avaient, alors qu'à côté d'eux, on ne comprenait rien à leur vaste solitude. (C'est tout le thème, au fond, de La Route d'Altamont où je n'ai pas cherché à dire beaucoup plus que cette déchirante vérité.) (143)

In her mid fifties when she wrote La Route, Roy seemed more willing to envisage consolations that would overcome at least temporarily these barriers.

\section{Conclusions}

In discussing Bonheur d'occasion Patrick Coleman has identified Roy's difficulty finding a vehicle to convey convincingly her insight that "an awareness of separation is a necessary condition of any moment of real connection" as one of her chief esthetic problems (77). Her successful negotiation of this tension in La Route d'Altamont owes much to presenting consolation as an antidote to separation. First, rather than deny the reality of separation, consolation mediates between it and union by allowing Roy to portray separation coexisting with communion; even the most stable consolations must be constantly renewed since consolation is more a process than a permanent state achieved once and for all. Consolation is adjusting to loss, not restoration of the lost object. It lessens the pain of separation, but does not heal the wound of absence completely. Second, the dialectic of absence and presence in consolation is enhanced by the retrospective first-person narrative form Roy uses particularly effectively in this novel. While retelling moments of shared joy, the older narrator can signal their transience, and likewise episodes of loss and dejection are retold in a way that reminds readers of the possibility of consolation. Furthermore the fact that the reader gradually realizes that older narrator Christine has become a writer makes the reflective nature of Roy's version of consolation more plausible. The mature writer-narrator intervenes frequently to interpret the experience of her younger self who was only just becoming aware of the sacrifices her emerging vocation would demand.

Consolation through nature and solidarity might have been more effective for Christine within the novel, and for Roy herself, were it not for the fact that grief is driven by guilt in Roy's case, and to a lesser extent in Christine's. Roy's own experience of separation and loss was heavily overlaid with her uneasiness over pursuing her career at the expense ties to family and the Franco-Manitoban 
community. ${ }^{16}$ Her grief over losing loved ones like her own mother was compounded by a feeling that she had not done enough for them, and thus her grief work tended to take the form of reparation. Roy will attempt to dissipate "le long malentendu de la vie" (DE 240) between herself and her mother by resurrecting Mélina in works like La Route d'Altamont.

But writing, at least for Roy personally, had its limits as a form of consolation. To be sure, as Carol Harvey notes, the act of writing her autobiographical fiction is consoling for Roy in that it creates a substitute for what she has lost. However, to the extent that such writing produces an idealized version of her life, or as Harvey as put it an alter ego who represents how she would have like to be (256), it pays tribute to wishful thinking and in extreme cases like "De quoi t'ennuies-tu, Eveline" skirts the illusory consolations that purport to abolish separation and to annul the loss.

Second, the excessive nature of her guilt inhibited successful resolution of her grief work through writing. A key passage of her autobiography suggests why Roy's attempts at auto-consolatory writing had to be constantly renewed. Roy maintains there that if the bereaved ruminate obsessively on the deceased, it is as much to console their lost loved ones for the pain the bereaved had caused the deceased as to console themselves: "les [les morts] consoler de la peine qu'ils se sont fait à notre sujet, et dont il me semble que nous ne pouvons les déliver même quand nous en sommes nous-mêmes délivrés" (103). But since the dead can neither be consoled nor grant final absolution, Roy's reparation through art is destined to remain unfinished. Rumination is generally considered one of the earlier tasks of the middle phase of grief work, and thus writing as rumination can offer at best only a modicum of permanent assuagement. The task of writing about her loved ones becomes a form of grief work, but given the overlay of guilt on her grief, it is grief work that will never be completed. Even Bonheur d'occasion is to some extent an open, uncompleted text, as seen in Roy's willingness in "Retour à Saint-Henri" to envisage the life of its characters after the novel's denouement. This is not surprising given that under its realist surface the novel is also, as Ricard shows, "un autoportrait" that transposed her own experience of family life (261). Even more obvious is the progression in Roy's last years from autobiographical fiction like the Manitoban cycle to the pure autobiography of La Détresse that she was unable to conclude. We see this to a lesser extent in La Route d'Altamont where the narrator Christine admits that she only came to understand much later that her writing is a work destined to remain in progress. "Mais toujours, toujours, je n'en étais qu'au commencement. Ignorant encore qu'il n'en pourrait jamais être qu'ainsi dans cette voie que j'avais prise..." (156).

The contrast between Freudian grief work and the traditional notion of consolation offers insight into this situation. While memory plays a key role in grief work according to Freud, ${ }^{17}$ understanding is more important in the consolatory process. In Freudian terms Roy's ruminations produce vivid, hypercathected memories of her lost family members; however, her guilt prevents the reality principle from performing its function of severing the ties with lost loved ones. Hence her incessant return in her autobiographical writing to her family. On the other hand, when these memories become the subject matter of her writing, the act of writing and its products provide substitutes for the missing loved ones, and some measure of consolation is available. This is because reflection is a key component of the consolatory process which the characters in her autobiographical writing undergo, and this reflective impulse in turn shapes the retrospective vision that transforms rumination into art, creating a sort of literary permanence that cannot be achieved in shifting human relationships.

Finally, the consolations of writing, like the satisfactions of any form of consolation, always entail accepting a diminishment. Writing about loved ones can create the verbal equivalent of mémère's photo album, but it is no replacement for the actual presence of loved ones and shared experiences. Moreover, as Christine Robinson has pointed out, La Route d'Altamont itself is in many ways a substitute for the Saga d'Eveline that Roy was unable to write (145): a collection of short stories has replaced an epic novel.

But once it is acknowledged that a measure of acquiescence to loss is a fundamental component of consolation, a very real gain accrues to the readers. Roy's own inability to write her mother's saga has given them one of her finest books. Indeed, much of this accomplishment stems from the fact that La Route $d^{\prime}$ Altamont avoids the overly facile compensations that tempted Roy herself and invites readers to weigh how moments of communion with nature and with other humans offer at least provisional aid in transcending life's inevitable separations and loss.

\section{Notes}

${ }^{1}$ Saint-Martin uses this correspondence as a point of departure for discussing Roy's relation both to her mother and her sisters in terms of Freudian grief theory.

${ }^{1}$ From "Ma petite rue qui m'a menée autour du monde" in Le pays de Bonheur d'occasion 50.

2 About half of the seventeen or so forms of the word consolation in the letters occur during her effort to console the dying nun.

${ }^{3}$ See M. Hanus for an overview of modern theory from a Freudian perspective that does not neglect the clinical aspects of mourning.

${ }^{4}$ Both David Payne and Donavan Ochs point to the rhetorical nature of consolation as a species of persuasion: the bereaved must be persuaded to accept a substitute or to do without the lost object. As Payne puts it, "To console is to persuade to a different order of valuations wherein a new persective on the loss is possible" (42). The ancient consolatory tradition was highly rhetorical as well. For example, the various arguments one might use to put a loss in a new perspective were analyzed in terms of the topoï. On the ancient rhetorical tradition of consolation considered in the broad cultural context of the GrecoRoman world, see Ochs. Carr relates the Christian adaptation of the ancient tradition to twentieth-century psychological theories.

${ }^{5}$ Christianity adapted itself quickly to what might be called a consolatory worldview. It promises consolation on earth for the fundamental loss, the separation from God caused by the Fall. The consolations that Christianity offers in this world for losses ranging from original sin to death will no longer be needed in heaven, where the saved will be reunited while experiencing fully the presence of God. The doctrine of the resurrection of believers provides intellectual consolation to the ber. Thed octror ments can be ments can be seen as providing affective consolation. Christ's redemption is thus the ultimate consolatory act; his Church provides temporary consolation until the Second Coming when all losses will be restored for believers and the need for consolation abolished.

${ }^{6}$ This solidarity with nature and with others, the feeling of being at ease in beautiful surroundings and loved recalls the experience that Roy recounts in La Détresse of her stay in Provence just before her return from Europe in 1939. "Est-ce parce que j"y fus le cour avide d'être consolé, et l'ai été au-delà de ce que j'espérais que j'ai tellement aimé la Provence?" (474). The idyll was one of the high points of her life: "Telle fut notre vie pen- 
dant un peu plus d'un mois, si heureuse qu'aujourd'hui, après tant de deuils et de peines gui m'ont rejointe, $j^{\prime}$ en rougirais pour un peu" (481)

7 In Détresse Roy notes that this story was inspired by her first day of teaching in Marchand (108). Ricard calls Cet été "un livre de deuil, tout entier hanté par la mort et l'abMarchand (108). Ricard cals Cet ete "comme le résumé ou l'emblème de tout l'ouvrage" sence" and notes that this story is "comme le resume ou writing rather in terms of their (455). I present these stories as emblems of two poles in her writing rather in terms of their place in her development. If "LEnfant morte" dates from around 1971 (Ricard 455) afte the completion of La Route d'Altamont, the rough draft of "Eveline" is roughly contemporary with $L a$ Route, but was prepared for publication by Ricard himself in 1982 (Ricard $515)$.

8 In a number of articles Kapetanovitch has emphasized this pessimistic side of Roy that he attributes to what he labels a Jansenist worldview $(1985,236 ; 1990,258)$. Paul Dube adopts much the same point of view, concluding, "A la fin, Gabrielle Roy demeure... une adopts much the sam (25). On the othedique et temporaire un maigre pallitif à son malheur d"ên "IIl (24-25). On the ou Socken attributes to her an optinistic philosophy: "Il]l y a moyen detre console. La mention de la consolation annonce lenchantement, c' est-à-dire la réconciliation des oppositions en surmontant le chagrin de la vie" (1989. 435-36). While he doesn't discuss the problem of evil in terms of consolation, Drummond deals with a number of the relevant issues and seems to come down more on the side of Socken than of Kapetanovitch.

9 Harvey summarizes well the relation between Christine and Roy: "Bien que Christine partage les traits de l'écrivaine, elle reste néanmoins fictive, un personage mixte où se retrouvent à la fois Gabrielle Roy telle qu'elle a été et comme elle aurait voulu être. Projetant l'image consolatrice d'un alter ego, l'auteure a créé ce personnage pour s'aider Pró elle a créé un moi et un monde mi-réel, mi-fictif pour effacer ses sentiments de culpabilité et pour se consoler des humiliations subies au passé" (256).

10 In a text in Le Pays de Bonheur d'occasion, written around 1948, Roy places this solidarity of generations explicitly under the sign of mourning. Visiting the Island of Sein at the extremity of Brittany, she sees in the fact that the women of the island, where the death of fishermen is frequent and everyone is related, never take off their black headdress of mourning, "l'essence même du deuil" (75): "[N]ous avons saisi l' image parfaite de la solidarité humaine. . . singulier sanctuaire du deuil, île de survie où l'amour et le mariag égalisaient tous devant la mort! Et les coiffes y déroulaient leur continuité, et elles étaien les mêmes pour les enterrements et pour les mariages imprégés de deuil et pour les sombres ex bres espoirs et pour les departs certains" (75-76). See Lewis

${ }_{11}$ the circular nature of the world and humanity (60-64). - manque, et tout est dépeuple "Saint-Hilaire paraphrases here a line ("Un seul être vous manque, et tout est depeuplé from "L"Isolement" by Lamartine. Roy maintained in La Détresse that she could not recal a single verse from Lamartine's equally famous "Le Lac," even though the poet was one of the few found suitable by the Church authorities to be included in the anthologies of her Catholic schooldays in Manitoba and she had written a prize-winning essay on the latter poem (71). If in "L'Isolement" the poet professes an indifference to nature and the world that Saint-Hilaire does not share, Lamartine's poem does evoke a region "au del des bornes" of the universe where love and hope can be found.

${ }^{12}$ One might say that just as Eveline is under the spell of her brother, the mother of the narrator of "LAlouette" falls under the spell of the songs of the Ukrainian lad Nil. singing combines the transforming power of "la vie du reve" with the experience of "la vie ver. (59). These who hear it find themselves in an enchanted state that is twice comvie vecue (59). Those who hear it find themselves in an renchan " (43) lighting the her pared to a dream (42). It vanquishe "loute la tristessedure (43) and restoring confidence in life (47). In the case of the narrator's mother, she finds the courage to rehabilitate herself from a broken hip. This miraculous cure is compared to a dream because desire is the motor force of the liberation it promises.

${ }^{13}$ Socken (1976) provides the most complete discussion of this vision of solidarity. He sees it as an ideal that is in part based in an nostalgic vision of the past, and is in part a goal to strive toward (323), seldom attained, but accessible just the same (310).

14 "Et me voici consolée, 'mon enfant, ma sœur" (213).
${ }^{15}$ For an elaborate reading from a psychoanalytic perspective of Roy's entire life in terms of reparation, see Wiktorowicz.

${ }^{16}$ Here is how Freud describes the interaction of memory and the verdict of reality in process of grief work in "Mourning and Melancholia": "Reality-testing has shown that the loved object no longer exists, and it proceeds to demand that all libido shall be withdrawn from its attachments to that object... it is a matter of general observation that people never willingly abandon a libidinal position, not even, indeed, when a substitute is already (244). "Each single one of the memories and situations of expectancy which demonstrate the libido's attachment to the lost object is met by the verdict of reality that the object no longer exists" (255)

Works Cited

Bell, Mark. Gabrielle Roy and Antoine de Saint-Exupéry: Terre des Hommes-Self and NonSelf. Frankfurt am Main: Peter Lang, 1991.

Bowlby, John. "Attachment Theory, Separation Anxiety, and Mourning." In New Psychiatric Frontiers, ed. David Hamburg. New York: Basic Books, 1978. 292-303.

Carr, Thomas M. Jr. "L'Ethos dans les rhétoriques de consolation de l'Ancien Régime à la lumière des perspectives récentes sur le deuil." In Ethos et Pathos. Le statut du sujet rhétorique, ed. Richard Lockwood and François Cornillat. Paris: Honoré Champion 2000. 320-35.

. "La Perte de l'autre et l'autoconsolation." In L'Autre au XVIlème Siècle. Biblio17 117 (1999): 367-73.

"Consolation and the Work of Mourning in Angéline de Montbrun.." The French Review 71 (1998): 997-1006.

. "Sharing Grief/ Initiating Consolation: Voltaire's Letters of Condolence." In Studies in Eighteenth-Century Culture 25 (1996): 131-46.

Coleman, Patrick. The Limits of Sympathy: Gabrielle Roy's The Tin Flute. Toronto: ECW Press, 1993.

Dorion, Gilles. "Gabrielle Roy." Québec français 36 (1979): 33-35.

Drummond, Dennis. "Alexandre Chenevert and The Book of Job." Essays in French Literature 27 (1990): 46-63.

Dubé, Paul. "Enoncé et énonciation: la rencontre du 'moi/je' dans La Détresse et l'enchantement." In Portes de communications, ed. Claude Romney. Sainte-Foy: PU Laval, 1995. 9-26.

Freud, Sigmund. Standard Edition of the Complete Psychological Works of Sigmund Freud, tr. James Strachey. vol.14. London: Hogarth Press, 1957.

Gagné, Marc. Visages de Gabrielle Roy, l'auvre et l'écrivain. Montréal: Beauchemin, 1973.

Harvey, Carol J. Le Cycle manitobain de Gabrielle Roy. Saint-Boniface: Les Editions des Plaines, 1993

Hanus, M. Les Deuils dans la vie. Deuils et séparations chez l'adulte et chez l'enfant. Paris: Maloine, 1994.

Kapetanovitch, Myo. "Alexandre Chenevert de Gabrielle Roy et les contradictions de son humanisme." In L'Ouest canadien et l'Amérique française, ed. Pierre-Yves Mocquais. Saint-Boniface: Centre d'études franco-canadiennes de l'Ouest, 1990. 251-58.

Lewis, Paula Gilbert. "The Resignation of Old Age, Sickness, and Death in the Fiction of Gabrielle Roy." American Review of Canadian Studies 11 (1981): 49-66.

Morisset, Jean. "Entre la détresse et le déchirement. Nature et signification de l'œuvre de Gabrielle Roy." In La Langue, la culture et la société des francophones de l'Ouest, ed. Annette Saint-Pierre and Liliane Rodriguez. Saint-Boniface: Centre d'études francocanadiennes de l'Ouest, 1985. 235-51.

Ochs, Donovan J. Consolatory Rhetoric. Grief, Symbol, and Ritual in the Greco-Roman Era. Columbia: South Carolina UP, 1993.

Payne, David. Coping with Failure: the Therapeutic Uses of Rhetoric. Columbia: South Carolina UP, 1989.

Ricard, François. Gabrielle Roy. Une vie. Montréal: Boréal, 1997. 
Robinson, Christine. "La Route d'Altamont de Gabrielle Roy, épave de La Saga d'Eveline?" Voix et images 23 (1997): 135-46.

Roy, Gabrielle. Bonheur d'occasion. Montréal: Stanké, 1977. . Ces Enfants de ma vie. Montréal: Stanké, 1977.

. Cet Eté qui chantait. Montréal: Boréal Compact, 1993.

. De Quoi t'ennuies-tu, Eveline? suivi de Ely! Ely! Ely! Montréal: Boréal Express, 1984.

. La Détresse et l'enchantement. Montréal: Boréal Compact, 1988.

Ma chère petite sæur. Lettres à Bernadette 1943-1970. Montréal: Boréal, 1988.

- La Route d'Altamont. Montréal: Boréal Compact, 1992.

Le Temps qui m'a manqué. Montréal: Boréal, 1997.

. Le Pays de Bonheur d'occasion. Montréal: Boréal, 2000.

Saint-Martin, Lori. "'Au plus près possible de vous tous'; deuil, distance et écriture dans la correspondance de Gabrielle Roy." In Les Femmes de lettres. Ecriture féminine ou spécificité générique?, éd. Benoît Melançon and Pierre Popovic. Montréal: Centre universitaire de lecture sociopolitique, 1994. 117-35.

Socken, Paul. "Le pays de l'amour in the Works of Gabrielle Roy." Revue de l'Université d'Ottawa 46 (1976): 307-23.

. "L'enchantement dans la détresse: l'irréconciliable réconcilié chez Gabrielle Roy." Voix et images 3 (1989): 433-36.

. "Ces Enfants de ma vie: l'apprentissage de Gabrielle Roy." Cahiers franco-canadiens de l'ouest 3 (1991): 15-30.

Wiktorowicz, Cécilia, "Retracer les configurations de la culpabilité et de la réparation dans La Détresse et l'enchantement." Colloque international Gabrielle Roy, ed. André Fauchon. Saint-Boniface, PU Saint-Boniface, 1996. 181-204. 